\title{
A Rare Case of Secondary Hydatid Cyst: Uterus and Colon Locations in the Same Patient
}

\author{
Nadir Bir Sekonder Kist Hidatik Olgusu: Ayn Hastada Uterus ve Kolon \\ Lokasyonu
}

\author{
(1) Yunus Emre Beyhan ${ }^{1}$, (1) Hasan Yılmaz ${ }^{1}$, (1) Zeynep Taş Cengiz ${ }^{1}$, (1) Recep Yıldızhan², (1) Çetin Kotan³ \\ (1) Abdussamet Batur ${ }^{4}$, (1) İrfan Bayram ${ }^{5}$, (1) Remzi Erten ${ }^{5}$, (1) Ahmed Galip Halidi ${ }^{6}$ \\ ${ }^{1}$ Yüzüncü Yll University Faculty of Medicine, Department of Parasitology, Van, Turkey \\ ${ }^{2}$ Yüzüncü Yll University Faculty of Medicine, Department of Obstetrics and Gynecology, Van, Turkey \\ ${ }^{3}$ Yüzüncü Yll University Faculty of Medicine, Department of General Surgery, Van, Turkey \\ ${ }^{4}$ Yüzüncü Yıl University Faculty of Medicine, Department of Radiology, Van, Turkey \\ ${ }^{5}$ Yüzüncü Yll University Faculty of Medicine, Department of Pathology, Van, Turkey \\ ${ }^{6}$ Muş Alparslan University, Bulanık Vocational School, Muş, Turkey
}

Cite this article as: Beyhan YE, Yllmaz H, Taş Cengiz Z, Yıldızhan R, Kotan R, Batur A, Bayram İ, Erten R, Halidi AG. A Rare

Case of Secondary Hydatid Cyst: Uterus and Colon Locations in the Same Patient. Turkiye Parazitol Derg. 2019;43(3): 149-51.

\begin{abstract}
The aim of the present study was to present a case with secondary hydatid cysts in both uterus and colon. The patient was a 71-yearold female living in Hakkari, Turkey. She was admitted to the Van Yuzuncu Yil University Faculty of Medicine Medical Center with complaints of chronic abdominal and pelvic pain, and swelling in the abdomen. First, the sagittal T2 weighted magnetic rezonance imaging (MR) showed a type-3 cyst hydatid with daughter vesicles located at the posterior of uterus. Later, MR revealed a type-2 cystic lesion with detached membrane adhered to the anterior wall of colon and it was reported to be associated with abdomen. When the previous liver surgery history of the patient was kept in mind, the new finding was suggestive of a secondary cystic hydatid. In conclusion, it is possible to diagnose secondary cystic echinococcosis in patients with a history of primary cyst surgery in liver or any other organ by combining the symptoms and imaging findings.
\end{abstract}

Keywords: Cystic echinococcosis, uterus, colon, MR, parasite

\section{ÖZ}

Bu çalışmanın amacı hem uterus hem de kolon yerleşimli bir sekonder hidatik kist olgusu sunmaktır. Hasta Hakkari'de yaşayan 71 yaşında bir kadındı. Van Yüzüncü Yıl Üniversitesi Dursun Odabaş Tıp Merkezi’ne kronik karın - pelvik bölge ağrısı ve karın şişliği şikayeti ile başvurdu. İlk olarak, sagittal T2 ağırlıklı manyetik rezonans (MR) görüntülerinde, uterus posteriorunda kız veziküllerin bulunduğu tip-3 kist hidatik saptandı. Daha sonraki MR'de, kolonun ön duvarına yapışmış ve karın ile ilişkili olduğu bildirilen ayrık membranlı tip-2 kistik bir lezyon ortaya çıkarıldı. Hastanın daha önce karaciğer cerrahisi öyküsü olması nedeniyle, olgu sekonder kistik hidatik olarak kabul edildi. Sonuç olarak, karaciğerde veya başka bir organda primer kist cerrahi öyküsü olan hastalarda semptomları ve görüntüleme bulgularını birleştirerek sekonder kistik ekinokokkozis tanısı koymak mümkündür.

Keywords: Kistik ekinokokkozis, uterus, kolon, MR, parazit

\section{INTRODUCTION}

Cystic echinococcosis (CE) is a common helminthic disease induced by the larval form of Echinococcus granulosus (E. granulosus). According to the World Health Organization data, this disease is endemic in South America, Eastern Europe, Russia, the Middle
East and China and exhibits a high annual incidence rate of 50 per 100.000 people in these regions $(1,2)$. In humans, the organs that $\mathrm{CE}$ is commonly observed are the liver and the lungs. Cysts are identified less frequently in other organs. Cysts may be localized in an organ and structure such as abdominal or pleural cavities, kidney, spleen, bone, brain, eye, ovary,

Received/Geliş Tarihi: 05.02.2019 Accepted/Kabul Tarihi: 22.07.2019

Address for Correspondence/Yazar Adresi: Yunus Emre Beyhan, Yüzüncü Yll University Faculty of Medicine, Department of Parasitology,

Van, Turkey

Phone/Tel: +90 5427719597 E-mail/E-Posta: yebeyhan@gmail.com ORCID ID: orcid.org/0000-0002-1696-4803 
testis or pancreas. In ruptured cysts, viable cystic content and intraperitoneal infiltration of protoscoleces and secondary hydatidosis may occur. Due to the slow growth and development of the cystic structure and the response of the host immune system, the disease may not be recognized for years. The symptoms could differ based on the size and localization of the cysts (1-4).

Clinical history, serologic tests and various imaging techniques such as ultrasonography (USG), computed tomography (CT) and magnetic resonance imaging (MRI) can help make the diagnosis of cyst hydatid (3-5).

The aim of the present study was to present a case with secondary hydatid cysts in both uterus and colon.

\section{CASE REPORT}

The patient was a 71-years-old female living in Hakkari, Turkey. She applied to the Van Yuzuncu Yil University Faculty of Medicine with complaints of chronic abdominal and pelvic pain, and swelling in the abdomen. The patient was admitted to the gynecology and obstetrics service with the diagnosis of pelvic mass (hydatid cyst + cholelithiasis (hydropic bladder) after the examinations. Certain hematologic, biochemical and microbiological parameters of the patient were studied. Results demonstrated that the white blood cell was 200.001/ $\mu \mathrm{L}(\uparrow)$, hemoglobin was $10.1 \mathrm{~g} / \mathrm{dL}(\downarrow)$, lymphocyte was $9.4 \%(\downarrow)$, c-reactive protein was $184 \mathrm{mg} / \mathrm{L}(\uparrow)$ and platelets was $70610^{\wedge} 3 / \mu \mathrm{L}(\uparrow)$. Other values were either normal or close to normal. Radiological MR and USG methods were used for definitive diagnosis. As a result of the evaluations, a cystic lesion of $12 \times 11 \mathrm{~cm}$ in size was observed in the uterus superior that applied pressure to the uterus and urinary bladder. The sagittal T2 weighted MR images showed a type- 3 cyst hydatid located at uterus posterior with daughter vesicles (Figure 1a, b,c). When the previous liver surgery history of the patient was considered, the new finding was considered to be a secondary cystic hydatid connected to that history. It was decided to operate on the patient with cystectomy and cholecystectomy methods based

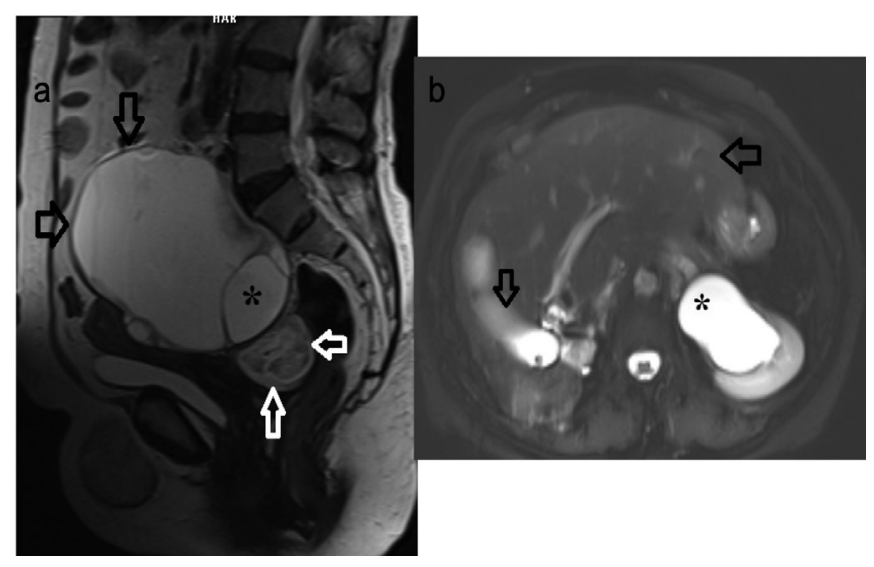

Figure 1. a) Sagittal T2-weighted MRI demonstrated (*) type 3 hydatid cyst (black arrows) with daughter vesicles located at the posterior of the uterus, and type 2 hydatid cyst with detached membrane in lesion posterior-interior (white arrow), b) Axial T2-weighted magnetic rezonance imaging demonstrated a decrease in the volume of the right lobe of the liver due to the operation and hypertrophy in the left lobe (arrows) and secondary hydroureteronephrosis on pelvic hydatid cyst impression $(*)$ on the findings. In the surgery, active chronic cervicitis, chronic cholecystitis and hydatid cyst were observed. Furthermore, extensive millimetric hydatid cysts calcifications were detected in the peritoneum. The cyst capsule was detracted from the rectum with sharp and obtuse dissections in the posterior and from the uterus and intestine mucosa in the anterior and the cyst was removed with the capsule. The obtained cyst material was sent to the pathology laboratory and uterus structure in cross-sections and cuticle membrane structure in tuba uterina were observed. After the surgery, the patient was discharged due to observation of no problems in postoperative follow-up. The patient applied to the chest surgery policlinic with a shortness of breath and chest pain one week after her discharge. Patient was re-admitted with the pre-diagnosis of hydatid cysts after the examinations. T2-weighted MR a type-2 cystic lesion with detached membrane adhered to the colon anterior wall and was reported to be associated with abdomen (Figure 2). Then the patient was transferred to the general surgery service. Here the patient was operated with low anterior resection + colorectal anastomosis. In the surgery, severe serositis, transmural infarction, hemorrhage and active chronic inflammation were detected. The resection material obtained from the colon was sent to the pathology laboratory for definite diagnosis and cuticle membrane of the

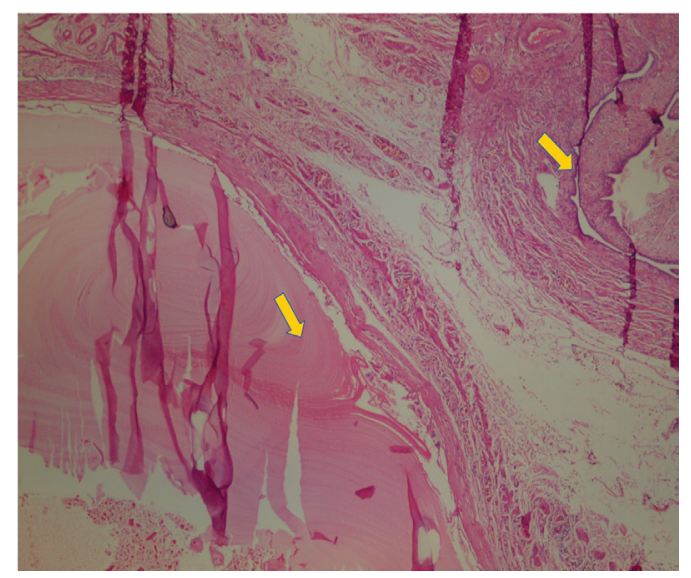

Figure 2. The membrane of cyst (left yellow label) and tuba uteraina (right yellow label) (hematoxylin-eosin, original magnification $\mathrm{x} 40$ )

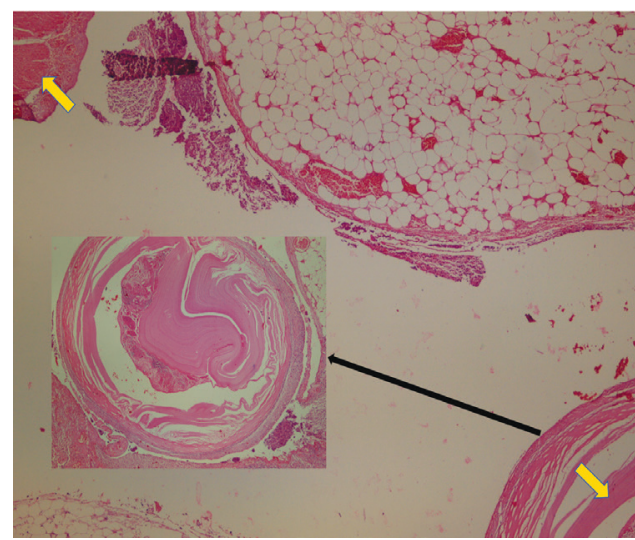

Figure 3. The muscular layer of colon (upper yellow label), membrane of cyst (bottom yellow label) and the cystic echinococcosis (black arrow) (hematoxylin-eosin, original magnification $\mathrm{x} 40$ ) 
colon and cyst were observed in the same preparation (Figure 3). The patient was admitted for two days and kept under control, and was discharged after the necessary treatments were provided and it was considered suitable to continue treatment for cyst hydatid with Andazol at a dose of 2x400 mg.

\section{DISCUSSION}

E. granulosus leads to a chronic unilocular, encapsulated, noninvasive cystic lesion that could grow up to $0.5-3 \mathrm{~cm}$ diameter annually and could be treated by surgical intervention. Prognosis of the disease is slowly and not fatal (6).

CE involvement is mostly in a single organ, and two organ involvement based on a specific geographic area and the strain of the parasite could be observed in $10-15 \%$ of the patients (7). Recurrence of primary hydatid cyst after surgery is $8-22 \%$ and recurrence usually occur in the first two years $(8,9)$. The incidence of pelvic $C E$ varies between 0.2 and $0.9 \%$. Ovary is the most common localization and the second is the uterus. In these cases, secondary cysts are formed as a result of the rupture of the primary cyst in other regions (8).

There are reports in the literature on the secondary hydatid cyst cases in uterus and colon (10), ovary and colon (5) due to the perforation of the primary cyst in the liver, and ruptured to the right colon from the liver (4). There are also primary $\mathrm{CE}$ cases reported due to involvement of the uterus (11) and colon (12). Although, Tas et al. (13), suspected an ovarian neoplasm in a 44-year-old menopausal patient with complaints of abdominal distention, they encountered primary ovary and omental $\mathrm{CE}$ during surgery. A case from Iran, primary uterus hydatid cyst removed from uterine on left ovary and fallopian tub of 46 years old women (14). In a six-year retrospective study of 18 patients treated surgically, localizations of CE were found in two tuba, one colon, omentum and uterus (15). In certain cases reported on these organs, information on whether the cyst was primary or secondary was not provided.

In literature review, it was observed that secondary $C E$ was not observed frequently in both uterus and colon. Since our case was operated for the hydatid cyst in the liver, it was recognized that cysts in these two organs were primary cysts from the liver. The pre-operative diagnosis of cysts in our case was conducted with USG, MRI and CT consistent with the literature $(3-6,11,12)$ and the cuticular layer of the cyst was revealed with histopathological methods post-operationally.

\section{CONCLUSION}

Primary involvement is rarely observed in organs such as colon and uterus in CE, secondary cysts may occur due to hepatic cyst surgery or spontaneous/traumatic rupture. In conclusion, it is possible to diagnose secondary $C E$ in patients with primary cyst surgery history in liver or any other organ by combining the symptoms and imaging findings.

\section{* Ethics}

Informed Consent: A consent form was completed by all participants.

\section{* Authorship Contributions}

Concept: Y.E.B., G.S., Design: Y.E.B., G.S., Data Collection or Processing: R.Y., G.K., A.B., İ.B., R.G., G.S., Analysis or Interpretation: Y.E.B., H.Y., A.B., Literature Search: Y.E.B., G.S., Z.T.C., Writing: Y.E.B., Z.T.C.

Conflict of Interest: No conflict of interest was declared by the authors.

Financial Disclosure: The authors declared that this study received no financial support.

\section{REFERENCES}

1. Agudelo Higuita NI, Brunetti E, McCloskey C. Cystic echinococcosis. J Clin Microbiol 2016;54:518-23.

2. Pakala T, Molina M, George Wu GY. Hepatic echinococcal cysts: A review. J Clin Transl Hepatol 2016;4:39-46.

3. Altıntaş N, Tınar R, Çoker A. Echinococcosis. Turkey; 2004.

4. Alan B, Kapan M, Budak H, Kuzu H. Intra-Abdominal Hydatidosis: Hydatid Cyst Related to Right Hepatic Colon Lumen. J Clin Expert Invest 2016;7:207-10.

5. Bougioukas IG, Courcoutsakis N, Korakianitis OS, Tentes AA, Prasopoulos P. Liver hydatid cyst perforated into the large bowel: a case report. Cases J 2009;18:6999.

6. Dharsandia MV, Soni ST, Vegad MM. Ovarian hydatid cyst in pediatric patient commencing as ovarian tumor: a rare site of echinococcosis. Int $\mathrm{J}$ Prev Med 2012;3:897-9.

7. Gottstein B. Hydatid Disease, Major Tropical Syndromes by Body System. Systemic infections, Cambridge: Cambridge University Press; section 6; p. 169.

8. Doğanay $\mathrm{M}$, Tonguç $\mathrm{E}$, Ustunyurt $\mathrm{E}$, Türker Tug $\mathrm{M}$, Bilge $\mathrm{U}$, Mollamahmutoğlu L. Differential Diagnosis of Tubal Hydatid Cyst in the Pelvic Masses. T Klin Jinekol Obst 2000;14:220-3.

9. Little JM, Hollands MJ, Ekberg H. Recurrence of hydatid disease. World J Surg 1988;12:700-4.

10. Sabir N, Yildirim B, Cetin B, Sengul M, Alatas E. A rare presentation of hydatid cyst. Saudi Med J 2005;26:1986-8.

11. Peker K, Uluğ P, Naykı ÜA, Naykı C, Sayar I, Karakeçili F, et al. Primary uterine hydatid cyst: a case report. Turkiye Parazitol Derg 2013;37:302-4.

12. Gavriilidis P, Ananiadis A, Theodoulidis V, Barbanis S. Primary retroperitoneal echinococcal cyst. BMJ Case Rep 2012;15:1-3.

13. Tas EE, Yegin Akcay GF, Yildirim F, Yavuz F. Coexisting Primary Ovarian and Omental Hydatid Disease Mimicking an Ovarian Neoplasm: A Case Report. Int J Gynecol Pathol 2018;37:301-4.

14. Kakaei F, Asvadi Kermani T, Tarvirdizade K. A case report: Primary hydatid cyst of uterus. Int J Surg Case Rep 2018;42:67-9.

15. Öztürk S, Ünver M, Güner M, Solmaz U, Mat E, Öztürk BK, et al. Unusual locations of intraabdominal hydatid cysts including gynecological organs; Clinical features and surgical outcomes of double center experience. J Surg Arts 2018;1:17-21. 